\title{
Multimedia Pollution Prevention of Mercury-Containing Waste and Articles: Case Study in Taiwan
}

\author{
Wen-Tien Tsai
}

check for updates

Citation: Tsai, W.-T. Multimedia Pollution Prevention of Mercury-Containing Waste and Articles: Case Study in Taiwan. Sustainability 2022, 14, 1557. https://doi.org/10.3390/su14031557

Academic Editor: Elena

Cristina Rada

Received: 24 December 2021

Accepted: 22 January 2022

Published: 28 January 2022

Publisher's Note: MDPI stays neutral with regard to jurisdictional claims in published maps and institutional affiliations.

Copyright: (C) 2022 by the author. Licensee MDPI, Basel, Switzerland. This article is an open access article distributed under the terms and conditions of the Creative Commons Attribution (CC BY) license (https:// creativecommons.org/licenses/by/ $4.0 /)$.
Graduate Institute of Bioresources, National Pingtung University of Science and Technology, Pingtung 912, Taiwan; wttsai@mail.npust.edu.tw; Tel.: +886-8-7703202

\begin{abstract}
In response to the Minamata Convention on Mercury, effective 16 August 2017, the Taiwan government in recent years started to implement the sustainable material management of mercurycontaining waste and articles. This was completed by a cross-ministerial collaboration for preventing the adverse effects of mercury on human health and the environment, based on the multimedia approach. The legislative or regulatory frameworks on the control and prevention of mercury emissions and releases have been established in environmental distributions, including air, water, soil, waste, food, and article (or commodity). Therefore, the central authorities included the Environmental Protection Administration (EPA), Council of Agriculture (COA), Ministry of Health and Welfare (MOHW), Ministry of Economic Affairs (MOEA), and Ministry of Labor (MOL). Furthermore, the implementation plans covered the reduction in mercury-containing products by restricted use and bans on its use, remediation of soil and groundwater for mercury-pollution sites, control of stationary source emissions, environmental monitoring, and compulsory recovery of mercury from electronic waste such as waste lightings. A successful case study on the recovery of mercury from electronic waste using a thermal treatment, and its capture control by activated carbon, was also addressed in this work. Due to the effectiveness of source control in Taiwan, the annual reported amount of mercury emissions from the stationary air pollution sources indicated a decreasing trend from 1.989 metric tons in 2016 to 1.760 metric tons in 2019. More significantly, the ministerial collaboration in implementing the Convention in Taiwan also echoed the United Nations (UN) Agenda 2030 for sustainable development goals (SDGs).
\end{abstract}

Keywords: mercury; sustainable material management; cross-ministerial implementation; regulatory measure; Taiwan

\section{Introduction}

Mercury $(\mathrm{Hg})$ naturally exists in various forms, including elemental mercury $\left(\mathrm{Hg}^{0}\right.$, metallic mercury, and mercury vapor); inorganic mercury $\left(\mathrm{Hg}^{+}\right.$and $\mathrm{Hg}^{2+}$, mercuric chloride, mercuric sulfide, and mercuric oxide); and organic mercury, such as methylmercury $\left(\mathrm{CH}_{3} \mathrm{Hg}\right.$ and $\left.\mathrm{MeHg}\right)$ [1]. Although it could be released into the environment from natural sources such as volcanic activity and weathering of rocks, human activities may be the main causes, especially in coal-fired power plants, industrial and mining processes (e.g., metal refineries), municipal solid waste incinerators, and other electronic waste recycling factories [2]. Once in the environment, mercury can be biologically transformed into $\mathrm{CH}_{3} \mathrm{Hg}$. In the study by Kosa and Kicińsk [3], the high content of $\mathrm{Hg}$ (i.e., $0.2187 \mathrm{mg} / \mathrm{kg}$ ) was found in the coal sample from the waste disposal site of the Siersza mine (Trzebinia, Poland). In this regard, wildlife and humans could be exposed to it through their diets due to bioaccumulation and biomagnification in the food web [4]. For example, Kicińska et al. determined the macroelement (e.g., $\mathrm{Ca}, \mathrm{Mg}$, and $\mathrm{Cu}$ ) and microelement (e.g., $\mathrm{Hg}, \mathrm{Pb}$, and $\mathrm{Cd}$ ) contents found in the liver of wild animals (e.g., deer) and farm animals (e.g., chicken) [5], showing that the regulatory limits were exceeded in $18 \%$ (for $\mathrm{Cd}$ and $\mathrm{Cu}$ ) and $9 \%$ (for $\mathrm{Hg}$ ) of the liver samples analyzed. These forms of mercury differ in their 
degrees of toxicity and their long-term effects on human health, especially in the nervous, digestive, immune, reproductive, and endocrine systems $[2,6]$. In addition, people may be exposed to mercury and its compounds under various situations, which mainly include food (e.g., fish and shellfish contaminated with $\mathrm{CH}_{3} \mathrm{Hg}$ ) ingestion. Exposure may also come from inhalation of elemental mercury vapors and their inorganic forms through the occupational environment and non-occupational atmospheric air [2,7]. Historically, Minamata disease may be the most famous case of mercury poisoning that occurred among Japanese residents of Minamata Bay from ingesting $\mathrm{CH}_{3} \mathrm{Hg}$-containing fish and shellfish during the 1950s [8-10]. In 2013, the United Nations (UN) signed the Minamata Convention on Mercury, which became effective on 16 August 2017, which is an international treaty to protect human health and the environment from the adverse effects of mercury and its transformed compounds such as $\mathrm{CH}_{3} \mathrm{Hg}$ [11]. More significantly, the ministerial collaboration in implementing the Convention in Taiwan also echoed the United Nations (UN) Agenda 2030 for sustainable development goals (SDGs). These relevant SDGs include Goal 1 (No poverty), Goal 2 (Zero hunger), Goal 3 (Good health and well-being), Goal 7 (Affordable and clean energy), Goal 9 (Decent work and economic growth), Goal 12 (Responsible consumption and production), and Goal 14 (Life below water) [12].

In Taiwan, exposure to mercury in the environment has become an increasing concern since the 1980s. Thereafter, the environmental and food monitoring studies have been reported in the literature [13-19], showing that the potential health hazards were positively associated with mercury inhalation and the ingestion of $\mathrm{CH}_{3} \mathrm{Hg}$-contaminated fish in the environmental media of the Taiwan area. The main sources of mercury emissions include coal-fired power plants [20], cement plants [21], solid incineration plants [22], and metal-sintering/smelting plants [23]. Owing to the presence of mercury in various media such as food, fertilizer, waste, and product, the effective control and management of mercury must cover the joint collaboration between ministries in Taiwan, including the Environmental Protection Administration (EPA), Council of Agriculture (COA), Ministry of Health and Welfare (MOHW), Ministry of Economic Affairs (MOEA), Ministry of Finance (MOF), and Ministry of Labor (MOL). Thereafter, the "Implementation Plan for the Minamata Convention on Mercury in Taiwan" was established and approved by executive Yuan on 27 June 2016. The main aim of this plan was to protect people's health and the environment from the hazards of mercury-containing articles and waste. Subsequently, the relevant regulations and monitoring surveys were performed to master the environmental distributions and to establish the regulatory framework for the management mechanism of mercury.

Before the 1980s, the most important mercury source could be from chlor-alkali plants [24]. However, the release of mercury and its compounds into the environment is still associated with industrial processes, coal-fired plants, and solid treatment facilities. Although the uses of mercury and mercury-containing products in Taiwan have been banned or strictly restricted in recent years, the regulatory and non-regulatory approaches will provide preventative strategies for other countries to learn from these mercury-related issues due to public concern about the human health risks. In addition, the regulatory implementation for controlling the emissions of mercury was rarely addressed in the literature. In this work, the emission inventory of mercury and its recovery case from electronic waste were based on the official open-accessed reports [25-27], which were mainly compiled from the EPA. Additionally, the information about the regulatory standards and measures for aiming at mercury emission reduction and separation recovery was accessed on the official website [28]. In brief, the main subjects thus covered the following key elements:

- Emission inventory of mercury in Taiwan;

- Regulatory measures relevant to the use and release of mercury;

- Case study in the recovery of mercury from electronic waste. 


\section{Status of Emission Inventory of Mercury in Taiwan}

To protect the environment and human health from exposure to mercury-containing media and to align with the international treaty for controlling mercury, the Taiwanese government has promulgated relevant regulations banning the production, import, sale, and use of related articles or products, which will be summarized in the next section. Based on the "Implementation Plan", the central competent authority in Taiwan (i.e., EPA) has conducted monitoring surveys on the national inventory sources of mercury. Figures 1 and 2 plot the relative percentages of the inventory sources of mercury and its origin from metal-smelting plants in 2019, respectively [25]. Furthermore, Taiwan's inventory sources of mercury in Figures 1 and 2 were briefly addressed as follows:

- $\quad$ The national mercury emissions in 2019 showed that the inventory sources in descending order were coal-fired power plants, metal-smelting plants, cement-manufacturing plants, asphalt-mixing plants, and waste incineration plants. The findings were consistent with those in other countries such as Japan [29] and Korea [30].

- The majority of mercury sources in the waste management sector came from municipal solid waste (MSW) incineration plants, accounting for about 91\%. The mercury emissions mostly came from fly ashes, which were produced from the incineration of the mercury-containing articles (e.g., lightings and dry batteries) mixed with municipal (non-hazardous) waste [31]. Therefore, the MSW incineration plants could pose a health risk due to the infiltration of the selected heavy metals into the environment.

- The mercury sources in the industrial processes sector were mostly from iron/steelmanufacturing and cement-manufacturing industries. As shown in Figure 2, the emissions of mercury from the metal-smelting plants included rotary kiln (for recovering zinc oxide from iron-manufacturing dust), sintering furnace (for manufacturing iron and non-ferrous metals such as copper and aluminum), and electric arc furnace (for manufacturing carbon steel, stainless steel, and alloy steel).

- Due to the effectiveness of source control in Taiwan, the annual emissions of mercury from the stationary air pollution sources indicated a gradual reduction from 1.989 metric tons in 2016 to 1.760 metric tons in 2019 [25]. Thus, the regulatory measures for controlling mercury emissions through the strict standards/limits and the restricted use and/or ban on mercury-containing articles will be further described in the next section.

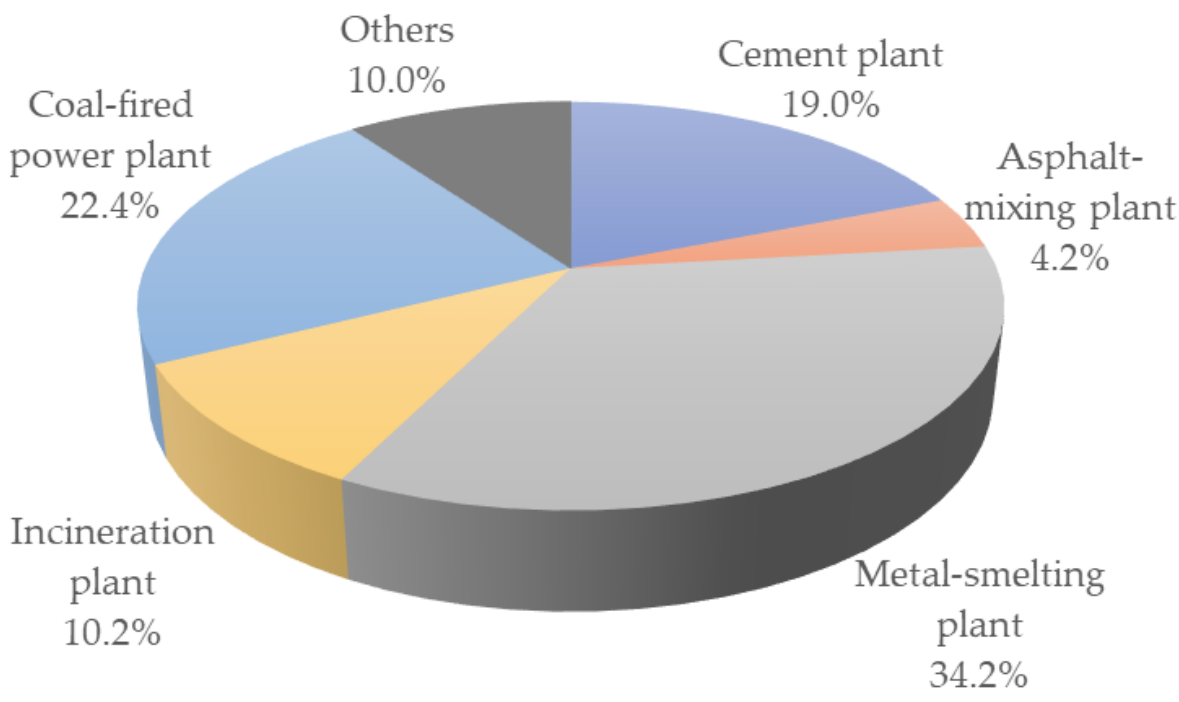

Figure 1. Taiwan's inventory sources of mercury in 2019 [25]. 


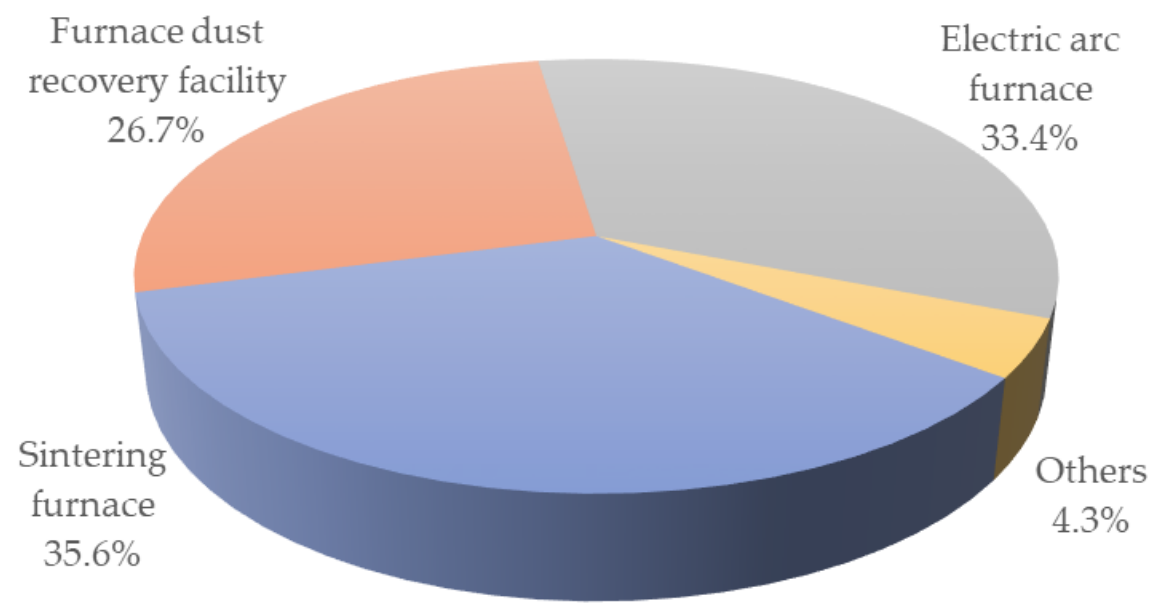

Figure 2. Taiwan's inventory sources of mercury from metal-smelting plants in 2019 [25].

\section{Regulatory Measures Relevant to the Use and Release of Mercury}

In review of the toxicity of mercury and its bioaccumulation feature in various media, the central governing authorities in Taiwan (including EPA, MOHW, COA, MOL, and MOEA) jointly promulgated the regulatory measures under the authorizations of various acts/laws passed by the congress [28], which will be summarized and addressed in the following sub-sections and Tables $1-3$. These regulations impacted society in different fields. For example, the annual certified quantity of waste from home electrical appliances still increased from 120,418 tons in 2017 to 139,010 tons in 2020 [32]. It showed that the high recycling rate of E-waste is significantly progressive under the 4-in-1 Recycling Program (i.e., public community, local authorities, recycling enterprises, and recycling fund) since 1998 [33]. It would be beneficial for these achievements to be in accordance with the regulations (Tables 1-3) concerning multimedia environments, which include air, water, soil, waste, food, and article (or commodity).

\subsection{Environmental Protection Administration}

In 1992, mercury ( $\mathrm{Hg}$ ) was designated as one of the toxic chemical substances under the Toxic and Concerned Chemical Substances Control Act (TCCSCA) [28]. It has been categorized as Class 1 toxic chemical substances. Class I toxic chemical substances are defined as those that do not decompose in the environment; that pollute the environment; or that endanger human health due to bioaccumulation, bioconcentration, or biotransformation. According to Article 11 of the TCCSCA, the EPA shall announce its control level (composition standards) and graded threshold handling quantity as $95 \mathrm{wt} \%$ and $50 \mathrm{~kg}$, respectively [28]. Conversely, the mercury will be present in the multimedia without decomposition or destruction once it is released into the environment from various emission sources. Based on these facts, the EPA has stipulated several regulations for controlling or preventing the impacts of mercury on environmental quality and human health. Table 1 listed the standards and/or limits of mercury under the promulgation of the relevant acts, including the Air Pollution Control Act (APCA), the Drinking Water Management Act (DWMA), the Water Pollution Control Act (WPCA), the Marine Pollution Control Act (MPCA), the Soil and Groundwater Pollution and Remediation Act (SGPRA), and the Waste Management Act (WMA) [28]. 
Table 1. The standards and/or limits of mercury under the promulgation by the EPA in Taiwan.

\begin{tabular}{|c|c|c|c|}
\hline Act & Regulation & Standards/Limits & Comments \\
\hline \multirow{3}{*}{ APCA } & Waste Incinerator Air Pollutant Emissions Standards & $0.05 \mathrm{mg} / \mathrm{Nm}^{3}$ & \\
\hline & \multirow{2}{*}{ Power Facility Air Pollutant Emissions Standards } & $\begin{array}{l}\text { Existing source: } 5 \mu \mathrm{g} / \mathrm{Nm}^{3} \\
\text { New source: } 2 \mu \mathrm{g} / \mathrm{Nm}^{3}\end{array}$ & $\begin{array}{ll}\text { - } & \text { Coal-fired steam boiler } \\
\text { - } & \text { Effective day: } 1 \text { December } 2014\end{array}$ \\
\hline & & $\begin{array}{l}\text { Existing source: } 3-13 \mu \mathrm{g} / \mathrm{Nm}^{3} \\
\text { New source: } 2-3 \mu \mathrm{g} / \mathrm{Nm}^{3}\end{array}$ & $\begin{array}{ll}\text { - } & \text { Coal-fired cogeneration boiler } \\
\text { - } & \text { Effective day: } 1 \text { December } 2014 \\
\text { - } & \text { Depending on total heat efficiency }\end{array}$ \\
\hline \multirow{2}{*}{ DWMA } & Drinking Water Quality Standards & $0.001 \mathrm{mg} / \mathrm{L}$ & \\
\hline & Drinking Water Sources Standards & $0.001 \mathrm{mg} / \mathrm{L}$ & \\
\hline \multirow{4}{*}{ WPCA } & \multirow[b]{2}{*}{ Effluent Standards } & $0.005 \mathrm{mg} / \mathrm{L}$ & Total mercury \\
\hline & & $0.002 \mathrm{mg} / \mathrm{L}$ & $\begin{array}{ll}- & \text { Total mercury } \\
- & \text { Effluent from FGD of coal-fired power plant }{ }^{1}\end{array}$ \\
\hline & Surface Water Classification and Water Quality Standards & $0.001 \mathrm{mg} / \mathrm{L}$ & $\begin{array}{ll} & \text { Total mercury } \\
- & \text { Pertaining to Protection of Human Health } \\
\end{array}$ \\
\hline & Marine Discharge Pipe Effluent Standards & $0.1 \mathrm{mg} / \mathrm{L}$ & $\begin{array}{ll}\text { - } & \text { Total mercury } \\
\text { - } & \text { Class A or B marine areas }\end{array}$ \\
\hline MPCA & $\begin{array}{l}\text { Maritime Environment Classification and Marine } \\
\text { Environment Quality Standards }\end{array}$ & $0.001 \mathrm{mg} / \mathrm{L}$ & \\
\hline \multirow{7}{*}{ SGPRA } & \multirow{2}{*}{ Soil Pollution Control Standards } & $20 \mathrm{mg} / \mathrm{kg}$ & \\
\hline & & $5 \mathrm{mg} / \mathrm{kg}$ & Crop farmland \\
\hline & Soil Treatment Standards & $0.005 \mathrm{mg} / \mathrm{L}$ & \\
\hline & \multirow{2}{*}{ Soil Pollution Monitoring Standards } & $10 \mathrm{mg} / \mathrm{kg}$ & \\
\hline & & $2 \mathrm{mg} / \mathrm{kg}$ & Crop farmland \\
\hline & \multirow[t]{2}{*}{ Groundwater Pollution Control Standards } & $0.002 \mathrm{mg} / \mathrm{L}$ & $\begin{array}{l}\text { Category 1: Groundwater in drinking water source } \\
\text { protection areas }\end{array}$ \\
\hline & & $0.02 \mathrm{mg} / \mathrm{L}$ & Category 1: Not of Category ${ }^{1}$ \\
\hline
\end{tabular}


Table 1. Cont.

\begin{tabular}{|c|c|c|c|}
\hline Act & Regulation & Standards/Limits & Comments \\
\hline \multirow{3}{*}{ SGPRA } & \multirow[t]{2}{*}{ Groundwater Pollution Monitoring Standards } & $0.001 \mathrm{mg} / \mathrm{L}$ & $\begin{array}{l}\text { Category 1: Groundwater in drinking water source } \\
\text { protection areas }\end{array}$ \\
\hline & & $0.01 \mathrm{mg} / \mathrm{L}$ & Category 1: Not of Category ${ }^{1}$ \\
\hline & $\begin{array}{c}\text { Sediments Quality Index Classification Management and } \\
\text { Use Restriction Measures }\end{array}$ & $\begin{array}{l}0.23 \mathrm{mg} / \mathrm{kg} \text { (Lower limit) } \\
0.87 \mathrm{mg} / \mathrm{kg} \text { (Upper limit) }\end{array}$ & \\
\hline \multirow{3}{*}{ WMA } & Standards for Defining Industrial Hazardous Waste & $0.2 \mathrm{mg} / \mathrm{L}$ & $\begin{array}{ll}- & \text { Mercury and its compounds } \\
\text { - } & \text { Based on TCLP }\end{array}$ \\
\hline & \multirow{2}{*}{$\begin{array}{l}\text { Methods and Facilities Standards for the Storage, } \\
\text { Clearance and Treatment of Industrial Waste }\end{array}$} & $0.2 \mathrm{mg} / \mathrm{L}$ & $\begin{array}{ll}\text { - } & \text { Waste containing } \geq 260 \mathrm{mg} / \mathrm{kg}(\mathrm{db}) \\
\text { - } & \text { Based on TCLP }\end{array}$ \\
\hline & & $0.025 \mathrm{mg} / \mathrm{L}$ & $\begin{array}{ll}\text { - } & \text { Waste containing }<260 \mathrm{mg} / \mathrm{kg}(\mathrm{db}) \\
\text { - } & \text { Based on TCLP }\end{array}$ \\
\hline
\end{tabular}

${ }^{1}$ FGD: Flue Gas Desulfurization; ${ }^{2}$ TCLP: Toxicity Characteristic Leaching Procedure.

Table 2. Maximal limits of total mercury and methylmercury in various foods in Taiwan [28].

\begin{tabular}{|c|c|c|c|c|}
\hline Act & Regulation & Food & Limits $(\mathrm{mg} / \mathrm{kg})$ & Comments \\
\hline \multirow{6}{*}{ FSSA } & \multirow{6}{*}{$\begin{array}{l}\text { Sanitation Standards for Contaminants and } \\
\text { Toxins in Food } \\
\left(\text { Implementation data: } 4 \text { February 2011) }{ }^{1}\right.\end{array}$} & Rice & 0.05 & \\
\hline & & Seaweed & 0.5 & Wet basis \\
\hline & & Edible fats and oils & 0.05 & $\begin{array}{l}\text { Intended for direct human } \\
\text { consumption, exclude marine oils }\end{array}$ \\
\hline & & Marine oils & 0.1 & \\
\hline & & Shark, swordfish, tuna, and oilfish & 2 & $\begin{array}{ll}\text { - } & \text { Methyl mercury } \\
\text { - } & \text { Wet basis }\end{array}$ \\
\hline & & $\begin{array}{l}\text { Grenadier, bonito, sea bream, catfish, } \\
\text { anglerfish/goosefishes, flounder/flatfish, mullet, rays, } \\
\text { scabbard fish, Parastromateus niger, sturgeon, } \\
\text { Scatophagus argus, eel, gold barracuda }\end{array}$ & 1 & $\begin{array}{ll}\text { - } & \text { Methyl mercury } \\
\text { - } & \text { Wet basis }\end{array}$ \\
\hline
\end{tabular}


Table 2. Cont.

\begin{tabular}{|c|c|c|c|c|}
\hline Act & Regulation & Food & Limits (mg/kg) & Comments \\
\hline \multirow{7}{*}{ FSSA } & \multirow{7}{*}{$\begin{array}{l}\text { Sanitation Standards for Contaminants and } \\
\text { Toxins in Food } \\
\text { (Implementation data: } 4 \text { February 2011) }\end{array}$} & Other fishes & 0.5 & $\begin{array}{ll}\text { - } & \text { Sea urchin, sea cucumber, and so on } \\
\text { - } & \text { Methyl mercury } \\
\text { - } & \text { Wet basis }\end{array}$ \\
\hline & & $\begin{array}{l}\text { Bivalve mollusks (excluding shells), Cephalopod } \\
\text { (exclude organ) }\end{array}$ & 0.5 & $\begin{array}{ll}\text { - } & \text { Methyl mercury } \\
\text { - } & \text { Wet basis }\end{array}$ \\
\hline & & $\begin{array}{c}\text { Muscle meat of crustaceans, including muscle meat } \\
\text { from appendages }\end{array}$ & 0.5 & $\begin{array}{ll}\text { - } & \text { Methyl mercury } \\
\text { - } & \text { Wet basis }\end{array}$ \\
\hline & & Other aquatic animals & 0.5 & $\begin{array}{ll}\text { - } & \text { Methyl mercury } \\
\text { - } & \text { Wet basis }\end{array}$ \\
\hline & & Bottled and packaged drinking water & 0.001 & \\
\hline & & Salt (food grade) ${ }^{1}$ & 0.1 & \\
\hline & & Ice cubes (food grade) ${ }^{2}$ & 0.001 & \\
\hline
\end{tabular}

${ }^{1}$ Food grade salt means obtained from the sea, from underground rock salt deposits, or from natural brine. It is used as an ingredient
food manufacture. ${ }^{2}$ The water complies with the Drinking Water Sources Standards. It is intended for direct human consumption.

Table 3. Maximal limits of total mercury in fertilizer under the promulgation by the COA in Taiwan [28].

Act

FMA

Regulation

Categories, Types and Specifications of Fertilizers

(Implementation data: 24 April 2020)

\section{Fertilizer Category and Types}

$$
\text { Nitrogen fertilizer category }
$$

Limits $(\mathrm{mg} / \mathrm{kg})$

(numic acid ammonium, Ammoni

$$
\text { by-product nitrogen, Solid-state hybrid nitrogen }
$$

Liquid-state by-product nitrogen, Liquid-state hybrid nitrogen

$$
\text { Phosphorus fertilizer category }
$$

Calcium superphosphate, Calcium triple superphosphate, Sintered phosphorus,

Smelt phosphorus, Humic acid phosphorus, Processed phosphorus, By-product phosphorus, Hybrid phosphorus, Ore-containing phosphorus powder 
Table 3. Cont.

Potassium sulfate, Potassium magnesium sulfate,

Humic acid potassium, Potassium silicate, Processed marinade potassium,

By-product potassium, Hybrid potassium

\section{Minor elements fertilizer category}

Magnesium sulfate, Humic acid magnesium, Magnesium lignosulfonate,

Processed magnesium, By-product magnesium, Hybrid magnesium,

Chelate-state magnesium, Quicklime, Slaked lime, Calcium carbonate, Shell

powder, By-product lime, Hybrid lime, Calcium sulfate, Dolomitic lime,

Dolomite powder, Siliceous limestone, Silicate slag, Processed boron,

Manganese sulfate, Slag manganese, Chelate-state manganese, By-product

manganese, Hybrid manganese, Zinc oxide, Zinc sulfate, Chelate-state zinc,

Chelate-state iron, Chelate-state copper, Smelt minor elements, Compound minor elements, Miscellaneous minor elements

Categories, Types and Specifications of Fertilizers

(Implementation data: 24 April 2020)
Liquid-state calcium, Liquid-state compound minor elements, Liquid-state miscellaneous minor elements

Vegetable (plant) dregs, By-product plant matter, Fish residue, Animal-derived

residue, By-product animal matter, Dry thallus, Nitrogen bird dung, Processed animal manure, Animal manure, General fertilizers, Miscellaneous fertilizers,

Hybrid organic fertilizers, Miscellaneous organic fertilizers

Liquid-state miscellaneous organic fertilizers, Liquid-state organic fertilizers

Compound fertilizer, Wrapped compound fertilizer, Home-gardening

compound fertilizer, Transformed compound fertilizer, Miscellaneous compound fertilizer,

Liquid-state compound fertilizer, Liquid-state miscellaneous compound fertilizer

$$
\text { Organic fertilizer category }
$$

$$
\text { Compound fertilizer category }
$$

Plant-growth aid

Humic acid 
Table 3. Cont.

Act

FMA
Regulation

Fertilizer Category and Types

Miscellaneous organic cultivation medium, Organic cultivation medium

Microbial fertilizer category

Categories, Types and Specifications

$$
\text { of Fertilizers }
$$

(Implementation data: 24 April 2020)
Leguminous rhizobium, Free azotobacter, Phosphate-solubilizing bacteria

Potassium-solubilizing bacteria, Compound microbial fertilizer, Arbuscular mycorrhiza
Limits (mg/kg) 
To be aligned with the Minamata Convention on Mercury, the EPA revised the "Restrictions on the Manufacture, Import, and Sale of Dry Batteries" in March 2015, which focused on the maximal permitted mercury content of dry batteries to be tightened as follows:

- $\quad$ Non-button-type batteries: 1 ppm, starting from 1 January 2016;

- $\quad$ Button-type batteries: 5 ppm, starting from 1 January 2016.

Furthermore, all manufacturers and importers of dry batteries must submit the necessary verification applications to their local environmental protection bureaus for acquiring the verification document of heavy metal contents starting from 1 July 2015. It was clear that the control of metal content of dry batteries at the source was aimed at reducing the emissions of mercury and other heavy metals (e.g., cadmium) from urban solid incineration plants and E-waste recycling processes. Conversely, the EPA announced the new regulation ("Restrictions on the Import of Mercury-Containing Products") under the authorization of the Waste Management Act on 25 August 2020. Starting from 1 January 2021, the following mercury-containing products, including imported products, would be banned:

- Switches and relays, but not including very high accuracy capacitance and loss measuring bridges, high-frequency radio frequency switches, and relays in monitoring and control instruments (with a maximum mercury content of $20 \mathrm{mg}$ per bridge, switch, or relay);

- High-pressure mercury lamps for general lighting;

- $\quad$ Non-electronic measuring instruments such as barometers, hygrometers, pressure gauges, thermometers (including body thermometers), and sphygmomanometers, but not including those installed in large equipment or used for high-precision measurement instruments.

\subsection{Ministry of Health and Welfare}

Due to the adverse effects of mercury and its compounds (e.g., methylmercury) on human health through the food chain, the central competent authority in Taiwan (i.e., (MOHW) stipulated the maximal limits of total mercury in various foods under the authorization of the Food Sanitation Management Act (FSMA), which is enacted to govern food sanitation, safety, and quality and to protect human health. Therefore, the new regulation ("Sanitation Standards for Contaminants and Toxins in Food") was announced on 8 May 2018 and revised on 4 February 2021. It should be noted that this new regulation was based on relevant regulations, which have been implemented for several years. Table 2 further lists the maximal limits of total mercury and methylmercury in various foods, including rice, seaweed, edible oil and fat, aquatic animals (i.e., fish, shellfish, and cephalopod), bottled and packaged drinking water, salt (food grade), and ice cube (food grade) [28].

\subsection{Council of Agriculture}

The Fertilizer Management Act, revised on 2002 June 19, was enacted to sustain soil fertility for promoting agricultural productivity and to protect the environment from pollution. The central competent authority for governing this Act is the Council of Agriculture (COA). Based on the legal definition, the "fertilizer" is a material that provides soils or plant tissues with nutrients or promotes nutrients utilization by them. Under the authorization of the Act, the COA thus promulgated the regulation regarding the categories, types, and specifications of fertilizers. Table 3 listed the maximal limits of total mercury in a variety of fertilizers [28].

\subsection{Ministry of Labor}

In Taiwan, the government promulgated mercury-related regulatory practices that protect workers' health in the workplace under the authorization of the Occupational Safety and Health Act (OSHA), which was executed by the Ministry of Labor (MOL) in the central government. In this respect, the most relevant regulations included the "Standards Governing Prevention of Specific Chemical Substances" and "Standards of Permissible Exposure Limits in Labor Workplace". Concerning the permissible exposure limits of 
mercury and related compounds in air based on $8 \mathrm{~h}$ time-weighted average concentration, the former (fume and its compounds) was set at $0.05 \mathrm{mg} / \mathrm{m}^{3}$, but the latter (the form of organic compounds) was set at $0.01 \mathrm{mg} / \mathrm{m}^{3}$. In addition, these mercury-containing hazardous substances have been noted as the "skin", which refers to the potentially significant contribution to the overall exposure by the cutaneous route, including skin and mucous membranes. It does not indicate that they will result in irritation, dermatitis, or allergy.

\subsection{Ministry of Economic Affairs}

The central competent authority for governing the affairs of industry and trade in Taiwan is the Ministry of Economic Affairs (MOEA). Regarding the management of mercurycontaining articles and commodities, the implementation agencies under the MOEA mainly include the Bureau of Industrial Development (BID); the Bureau of Foreign Trade (BFT); and the Bureau of Standards, Metrology \& Inspection (BSMI). In response to the national plan for implementing the Minamata Convention on Mercury, the following measures were performed by the appropriate bureau:

- $\quad$ BID: Under the authorizations of the Statue for Industrial Innovation and the Factory Management Act, the BID assisted the industrial enterprises with the measures of mercury-related control, and prevention and alternative operations.

- BFT: Based on the regulations of export/import of commodities under the authorization of the Trade Act, the BFT promulgated the standard classifications of mercurycontained commodities, which were listed as restricted for use.

- $\quad$ BSMI: Under the authorizations of the Commodity Inspection Act, the BSMI issued the national standards for the commodities (e.g., toy) to ensure consumer rights. The limit of mercury content is set to $60 \mathrm{mg} / \mathrm{kg}$ for the commodities or to be in accordance with the related regulations.

\section{Case Study in the Recovery of Mercury from Electronic Waste}

In the past decades, Taiwan has become famous for its Information and communication Technology (ICT) industry around the world, thus causing a significant increase in the production and consumption of electrical and electronic products. As a consequence, the collection, recovery, and treatment of electronic waste (E-waste), such as spent dry batteries and lightings, has become a vital issue in urban waste management because they may contain toxic mercury and other valuable materials such as aluminum and copper [34,35]. Figures 3 and 4 indicated the reported collection amounts of waste lightings and waste dry batteries from 2012 to 2020 in Taiwan, respectively, by referring to the official database [32]. The gradual decreases were due to the restricted use and/or bans on the mercury-containing articles in recent years by implementing regulatory measures.

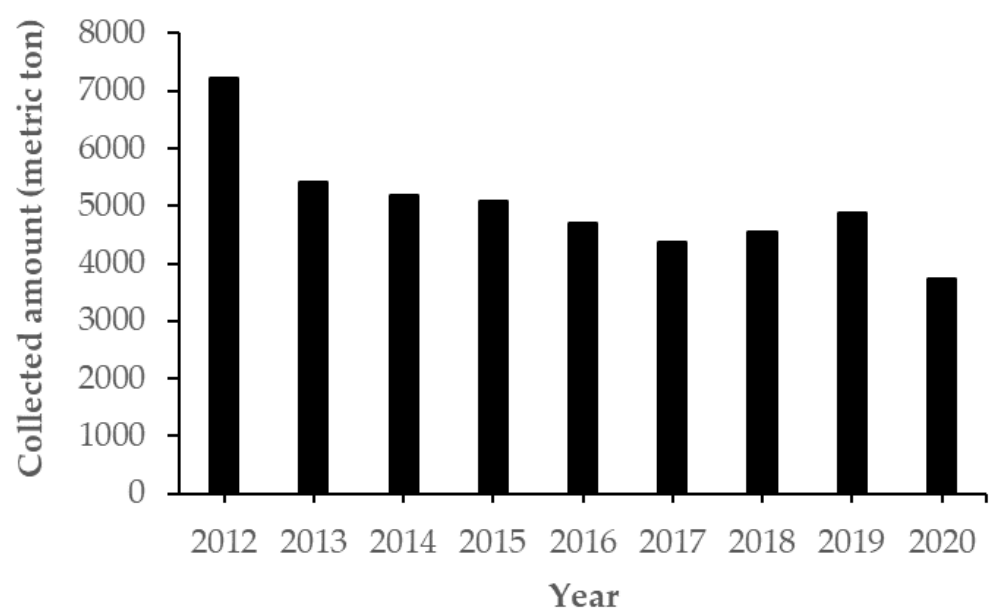

Figure 3. Collected amounts of waste lightings during the period of 2012-2020 in Taiwan [29]. 


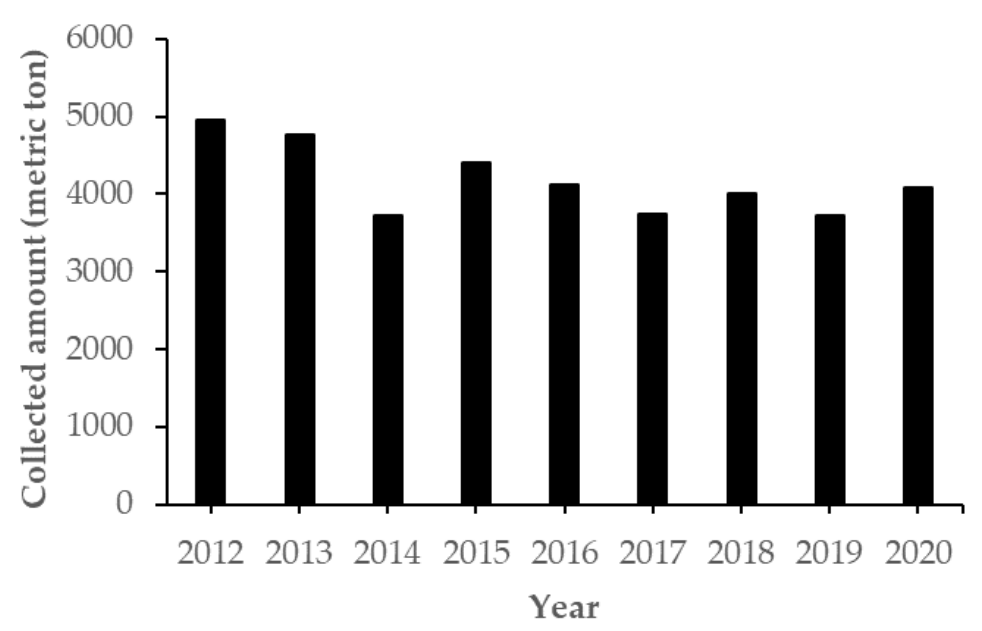

Figure 4. Collected amounts of waste from dry batteries from 2012 to 2020 in Taiwan [29].

According to the regulations governing the recovery of mercury from electronic waste such as lightings and dry batteries, the waste cold cathode fluorescent lamps (CCFLs), button-type batteries, and other kinds of lamps/dry batteries must be collected, reported, and treated through the 4-in-1 Recycling Program because of the toxic materials (e.g., mercury) and valuable materials (i.e., glass, metal, and plastic) involved [33]. Concerning the regulatory requirements for the treatment equipment of waste lightings and dry batteries, the relevant measures included the following items:

- Mercury vapor will not be released into the atmosphere. Therefore, the mercurycontaining components / parts must be collected by non-destruction (physical damage) methods and stored in a separated and closed container with the functions of leakageproof and effusion-proof.

- The mercury-containing components/parts must not be mixed with non-regulated waste during recycling (mechanical treatment). Currently, a commercial thermal desorption (or vacuum-distillation) system (MRT System AB, Sweden) has been adopted to recover mercury from mercury-containing waste by a condenser $[36,37]$. The condensed mercury will be further refined to produce the high-purity liquid mercury $(>99.99 \%)$.

- In order to prevent mercury vapor leakage, the closed system must be adopted in the generation zone of mercury vapor. It must also be operated under negative pressure in the inlet and outlet by installing a pressure gauge for continuous monitoring. In addition, the vent gas must be collected and further treated efficiently. In this regard, the vent gas from the treatment process containing mercury vapor shall be adsorbed (or captured) by sulfur-impregnated activated carbon.

- The recycling system must be equipped with mercury detectors and flowrate meters to continuously monitor the mercury concentrations of the inlet and outlet.

\section{Conclusions}

In response to the Minamata Convention, the Taiwanese government has announced the implementation plans for preventing or reducing the adverse effects of mercury on human health and the environment under the collaboration between ministries since 2016. Based on the multimedia approach, the regulatory and non-regulatory measures for reducing mercury emissions include restricted use and bans on the uses (import and manufacture) of mercury-containing products; reduction in stationary source emissions; environmental and food monitoring; remediation soil and groundwater pollution sites; and the compulsory recovery of mercury from electronic waste, such as lightings and dry batteries. According to the EPA's survey on stationary air pollution sources, the annual mercury emission amounts indicated a decreasing trend from 1.989 metric ton in 2016 to 1.760 metric ton in 2019. These results could be associated with the effectiveness of the 
implementation plan for source control in Taiwan, under the authorizations of various relevant acts/laws, which are powered by cross-ministerial authorities. In conclusion, these sustainable material management approaches for preventing and controlling mercury emissions not only reduce the hazard risks of human health and the environment but also promote green productivity and corporate social responsibility (CSR) for sustainable development goals (SDGs).

Funding: This research received no external funding.

Institutional Review Board Statement: Not applicable.

Informed Consent Statement: Not applicable.

Data Availability Statement: The data is contained within the article.

Conflicts of Interest: The author declares no conflict of interest.

\section{References}

1. Raj, D.; Maiti, S.K. Sources, toxicity, and remediation of mercury: An essence review. Environ. Monit. Assess. 2019, 191, 566. [CrossRef] [PubMed]

2. Beckers, F.; Rinklebe, J. Cycling of mercury in the environment: Sources, fate, and human health implications: A review. Crit. Rev. Environ. Sci. Technol. 2017, 47, 693-794. [CrossRef]

3. Kosa, B.; Kicińska, A. Coal from the waste disposal site of the Siersza mine (Trzebinia, Poland) and its properties as a possible alternative fuel. E3S Web Conf. 2016, 10, 00039. [CrossRef]

4. Mercury and Health. Available online: https://www.who.int/news-room/fact-sheets/detail/mercury-and-health (accessed on 18 October 2021).

5. Kicińska, A.; Glichowska, P.; Mamak, M. Micro- and macroelement contents in the liver of farm and wild animals and the health risks involved in liver consumption. Environ. Monit. Assess. 2019, 191, 132. [CrossRef]

6. Henriques, M.C.; Loureiro, S.; Fardilha, M.; Herdeiro, M.T. Exposure to mercury and human reproductive health: A systematic review. Reprod. Toxicol. 2019, 85, 93-103. [CrossRef]

7. Sundseth, K.; Jozef, M.; Pacyna, J.M.; Pacyna, E.G.; Pirrone, N.; Thorne, R.J. Global sources and pathways of mercury in the context of human health. Int. J. Environ. Res. Public Health 2017, 14, 105. [CrossRef]

8. Ishihara, N. Historical review of the toxicity of organic mercury compounds in relation to the Minamata disease. Trace Elem. Electroly. 2011, 28, 196-198. [CrossRef]

9. Sakamoto, M.; Tatsuta, N.; Izumo, K.; Phan, P.T.; Vu, L.D.; Yamamoto, M.; Nakamura, M.; Nakai, K.; Murata, K. Health impacts and biomarkers of prenatal exposure to methylmercury: Lessons from Minamata, Japan. Toxics 2018, 6, 45. [CrossRef]

10. Saturday, A. Mercury and its associated impacts on environment and human health: A review. J. Environ. Health Sci. 2018, 4, 37-43.

11. Perrez, F.X. The Role of the United Nations Environment Assembly in emerging issues of international environmental law. Sustainability 2020, 12, 5680. [CrossRef]

12. Take Action for the Sustainable Development Goals (United States). Available online: https://www.un.org/sustainabledevelopment/ sustainable-development-goals / (accessed on 20 January 2022).

13. Chen, Y.C.; Chen, M.H. Mercury levels of seafood commonly consumed in Taiwan. J. Food Drug Anal. 2006, 14, 373-378. [CrossRef]

14. Jiang, C.B.; Yeh, C.Y.; Lee, H.C.; Chen, M.J.; Hung, F.Y.; Fang, S.S.; Chien, L.C. Mercury concentration in meconium and risk assessment of fish consumption among pregnant women in Taiwan. Sci. Total Environ. 2010, 408, 518-523. [CrossRef] [PubMed]

15. Tsai, C.F.; Shih, D.Y.C.; Shyu, Y.T. Survey of total mercury in foods from Taiwan containing red mould rice (Monascus) using a direct mercury analyser (DMA). Food Addit. Contam. Part B Surveill. 2010, 3, 84-89. [CrossRef]

16. Dong, C.D.; Chen, C.W.; Chen, C.F. Distribution, enrichment, accumulation and potential ecological risks of mercury in the sediments of Kaohsiung Harbor, Taiwan. Chem. Ecol. 2013, 29, 693-708. [CrossRef]

17. Wang, Y.L.; Fang, M.D.; Chien, L.C.; Lin, C.C.; His, H.C. Distribution of mercury and methylmercury in surface water and surface sediment of river, irrigation canal, reservoir, and wetland in Taiwan. Environ. Sci. Pollut. Res. 2019, 26, 17762-17773. [CrossRef]

18. Tseng, C.H.; Chen, L.L.; Hsi, H.C.; Lee, M.C. Modeling of exposure to mercury in different environmental media over a 30-year period-A case study of Shimen reservoir, northern Taiwan. Hum. Ecol. Risk Assess. 2020, 26, 1379-1390. [CrossRef]

19. Fang, T.H.; Lien, C.Y. Different Mercury Species Partitioning and Distribution in the Water and Sediment of a Eutrophic Estuary in Northern Taiwan. Water 2021, 13, 2471. [CrossRef]

20. Hsi, H.C.; Lee, H.H.; Hwang, J.F.; Chen, W. Mercury speciation and distribution in a 660-megawatt utility boiler in Taiwan firing bituminous coals. J. Air Waste Manag. Assoc. 2010, 60, 514-522. [CrossRef]

21. Chou, C.P.; Chang, T.C.; Chiu, C.H.; His, H.C. Mercury speciation and mass distribution of cement production process in Taiwan. Aerosol Air Qual. Res. 2018, 18, 2801-2812. [CrossRef] 
22. Huang, J.Y.; Liu, C.K.; Huang, C.S.; Fang, G.C. Atmospheric mercury pollution at an urban site in central Taiwan: Mercury emission sources at ground level. Chemosphere 2012, 87, 579-585. [CrossRef]

23. Fang, G.C.; Jhang, Y.M.; Lin, Y.H.; Lin, S.M. Total mercury and particulate-bound mercury concentrations and content in ambient air in central Taiwan. Environ. Forensics 2012, 13, 203-208. [CrossRef]

24. Kismelyeva, S.; Khalikhan, R.; Torezhan, A.; Kumisbek, A.; Akimzhanova, Z.; Karaca, F.; Guney, M. Potential human exposure to mercury $(\mathrm{Hg})$ in a chlor-alkali plant impacted zone: Risk characterization using updated site assessment data. Sustainability 2021, 13, 13816. [CrossRef]

25. Environmental Protection Administration (EPA). Implementation Plan for the Minamata Convention on Mercury in Taiwan; EPA: Taipei, Taiwan, 2021. (In Chinese)

26. Lin, C.F. Compliance with Minamata Convention on Mercury: Strategies and Implementation Plan in Taiwan. In Proceedings of the 2019 International Chemical and Mercury Management Conference, Taipei, Taiwan, 7-8 August 2018.

27. Asian Productivity Organization (APO). Overview and Case Studies on Resources Recycling in the R.O.C. 2013; Industrial Development Bureau (Ministry of Economic Affairs): Taipei, Taiwan, 2018.

28. Ministry of Justice. Laws and Regulation Retrieving System. Available online: https://law.moj.gov.tw/Eng/index.aspx (accessed on 13 October 2021).

29. Nansai, K.; Oguchi, M.; Suzuki, N.; Kida, A.; Nataami, T.; Tanaka, C.; Haga, M. High-resolution inventory of Japanese anthropogenic mercury emissions. Environ. Sci. Technol. 2012, 46, 4933-4940. [CrossRef] [PubMed]

30. Kim, J.H.; Park, J.M.; Lee, S.B.; Pudasainee, D.; Seo, Y.C. Anthropogenic mercury emission inventory with emission factors and total emission in Korea. Atmos. Environ. 2010, 44, 2714-2721. [CrossRef]

31. Kicińska, A. Chemical and mineral composition of fly ashes from home furnaces, and health and environmental risk related to their presence in the environment. Chemosphere 2019, 215, 574-585. [CrossRef]

32. Environmental Protection Administration (EPA, Taiwan). Yearbook of Environmental Protection Statistics 2020; EPA: Taipei, Taiwan, 2021

33. EPA. Recycling Fund Management Board. Available online: https://recycle.epa.gov.tw/ConvenienceServices/Downloads (accessed on 16 October 2021).

34. Tsai, W.T. Recycling waste electrical and electronic equipment (WEEE) and the management of its toxic substances in Taiwan-A case study. Toxics 2020, 8, 48. [CrossRef]

35. Tsai, W.T. Current practice and policy for transforming E-waste into urban mining: Case study in Taiwan. Int. J. Environ. Waste Manag. 2019, 23, 1-15. [CrossRef]

36. Chang, T.C.; You, S.J.; Yu, B.S.; Chen, C.M.; Chiu, Y.C. Treating high-mercury-containing lamps using full-scale thermal desorption technology. J. Hazard. Mater. 2009, 162, 967-972. [CrossRef]

37. Lee, C.H.; Popuri, S.R.; Peng, Y.H.; Fang, S.S.; Lin, K.L.; Fan, K.S.; Chang, T.C. Overview on industrial recycling technologies and management strategies of end-of-life fluorescent lamps in Taiwan and other developed countries. J. Mater. Cycles Waste Manag. 2015, 17, 312-323. [CrossRef] 